\title{
Seroprevalence of human coronaviruses among patients visiting Hospital-Based Sentinel Sites in Uganda
}

Elijah Mulabbi ( $\nabla$ nichelijah@gmail.com )

Makerere University

Robert Tweyongyere

Makerere University

Fred Wabwire

Makerere University

Edison Mworozi

Mulago Hospital

Jeff Koehlerb

Makerere University Walter Reed Project

Hannah Kibuuka

Makerere University Walter Reed Project

Monica Millard

Makerere University Walter Reed Project

Bernard Erima

Makerere University Walter Reed Project

Titus Tugume

Makerere University Walter Reed Project

Ukuli Aquino

Makerere University Walter Reed Project

Denis Byarugaba

Makerere University

\section{Research Article}

Keywords: Human coronaviruses, fibril illnesses, emerging viral infections

Posted Date: December 10th, 2020

DOI: https://doi.org/10.21203/rs.3.rs-116084/v1 
License: (c) (i) This work is licensed under a Creative Commons Attribution 4.0 International License. Read Full License 


\section{Abstract}

Background: Human coronaviruses are causative agents of respiratory infections with several subtypes being prevalent worldwide. They cause respiratory illnesses of varying severity and have been described to be continuously emerging but their prevalence is not well documented in Uganda. This study assessed the seroprevalence of antibodies against the previously known human coronaviruses prior 2019 in Uganda.

Methods: A total 377 serum samples collected from volunteers that showed influenza like illness in five hospital-based sentinel sites and archived were analyzed using a commercial Qualitative Human Coronavirus Antibody IgG ELISA kit. Although there is no single kit available that can detect the presence of all the circulating coronaviruses, this kit uses a nucleoprotein, aa 340-390 to coat the wells and since there is significant homology among the various human coronavirus strains with regards to the coded for proteins, there is significant cross reactivity beyond HCoV HKU-39849 2003. This gives the kit a qualitative ability to detect the presence of human coronavirus antibodies in a sample.

Results: The overall seroprevalence for all the sites was $87.53 \%$ with no significant difference in the seroprevalence between the Hospital based sentinel sites $(p=0.8)$. Of the seropositive, the age group 1-5 years had the highest percentage (46.97), followed by 6-10 years (16.67) and then above 20 (16.36). The volunteers were divided into two broad categories, those below five years and those above five years, to calculate the odds ratio. The odds ratio of those seropositive with an age above 5 years with reference to those below 5 years was 0.62 . This shows that those below 5 are more likely to be seropositive compared to those above 5 years. The seropositivity was generally high throughout the year with highest being recorded in March and the lowest in February and December.

Conclusions: The seroprevalence of Human coronaviruses is alarmingly high which calls for need to identify and characterize the circulating coronavirus strains so as to guide policy on the control strategies.

\section{Background}

Human coronaviruses are common causative agents of respiratory infections with several subtypes being prevalent in many parts of the world. Coronaviruses are a complex group of viruses of the subfamily Coronavirinae in the family Coronaviridae of the order Nidovirales $(1,2)$. This subfamily has four genera: Alphacoronaviruses, Betacoronaviruses, Gammacoronaviruses and Deltacoronaviruses, of which Alphacoronaviruses (HCoV-229E and HCoV-NL63) and Betacoronaviruses(HCoV-HKU1, SARS-CoV, HCoV-OC43 and MERS-CoV) infect humans $(3,4)$. They are enveloped with a linear, non-segmented, positive sense, single-stranded RNA genome ranging between $27 \mathrm{~kb}$ to $32 \mathrm{~kb}$ which shows that they are the largest among the RNA viruses $(5,6)$. Although they are phenotypically and genotypically diverse, they possess a common genomic organization with the replicase gene occupying two thirds of 5 ' end of the genome in which two overlapping large open reading frames, ORF1a and ORF1b are found $(5,7)$. The 
ORF1b is the most highly conserved part of the genome encoding for conserved roles such as polymerase and helicase activities $(8,9)$. The remaining one third of the genome at the 3 ' end carries genes that encode for a set of structural proteins in the order $5^{\prime}$-spike $(S)$ to envelope $(E)$ to membrane $(\mathrm{M})$ and lastly nucleocapsid (N) (5). The Nucleocapsid protein binds to the genome and elicits a humoral immune response because it contains several linear epitopes (10) while the spike protein which is the largest, forms oligomonomers on the virus surface.

Human coronaviruses were first discovered in the 1960s as causative agents of self-limited upper respiratory tract infections and until 2002, they were known to cause mild infections but this changed with the emergence of Severe Acute Respiratory Syndrome Coronavirus (SARS-CoV) $(11,12)$. To date there are seven known Human coronaviruses (HCoVs) that have been identified, these are HCoV-229E, HCoV-NL63, HCoV-OC43, HCoV-HKU1, SARS-CoV, MERS-CoV and the newest discovered, SARS-CoV-2 (4, 13). The first four HCoVs have been well known to be of worldwide distribution causing approximately $33.3 \%$ of human common cold infections (14). However in some cases, these can cause severe illness in the elderly, children and all immunocompromised persons and patients especially those with underlying infections medical conditions like diabetes, hypertension, tuberculosis and AIDs $(15,16)$. SARS-CoV suddenly emerged in Guangdong Province of China in 2002 causing severe pneumonia characterized by fever, headache and cough but later develops into life threatening respiratory failure and distress (17). The first cases to be diagnosed with SARS were food handlers and workers in wet live-animals' markets, but soon the disease spread to several countries in a short period infecting more than 8000 people with a mortality rate of $10-11 \%(18-20)$. SARS-CoV is believed to have been spilled over to human populations from civets that are intermediate host for SARS-CoV since it has been traced back to bats as their natural hosts (21). After ten years, in 2012, MERS-CoV appeared in Saudi Arabia causing severe human respiratory disease with clinical presentation similar to SARS-CoV but with a higher fatality rate of $35 \%$ $(22,23)$. MERS-CoV found its way into human population from bats via dromedary camels but unlike SARS-CoV, cases of MERS-CoV infections have been restricted to the Arabian Peninsula and cases outside this Peninsula like the outbreak that occurred in South Korea, the index patient had traveled to Saudi Arabia and United Arabs Emirates thus tracing the source of infection back to the Arabian Peninsula $(24,25)$. Currently the world is facing a pandemic caused by a novel human coronavirus that started from the Hubei Province in China and now has spread the whole world, this novel coronavirus that had been previous named 2019-nCoV is now known as SARS-CoV-2 due to its similarity to the symptoms induced by SARS-CoV(26-28). Initial studies of SARS-CoV-2, linked the infection to a wet wild animal market in Wuhan but genetic analysis have shown that it is similar to a coronavirus that had been isolated from bats but transmitted to human through a yet to be confirmed intermediate host (29). Nevertheless, studies have showed that human to human transmission through droplets and direct contact has been the most important mode of transmission to regions outside Hubei especially by asymptomatic carriers traveling from one area to another $(30,31)$.

Seroprevalence studies are important in understanding the prevalence of subclinical human coronavirus infections and the population's herd immunity against these viruses. The Seroprevalence of human coronaviruses varies greatly among studies because of the different antigens, methodologies used, age 
and other demographic characteristics of the population studied (32). The Seroprevalence estimates for Human coronaviruses range from $5-30 \%$ of all respiratory infections with up to $21.6 \%$ of the general population having serum antibodies $(33,34)$. In a previous study to estimate the exposure level of individuals to the circulating coronaviruses in the U.S. Metropolitan population, established $91.3 \%, 59.2 \%$, 91.8\% and 90.8\% seropositive for HCoV 229E, HKU1, NL63 and OC43 respectively which is similar to studies that showed $99 \%, 91 \%, 98 \%$ and $100 \%$ seropositive for the respective human coronaviruses (32, 35). These findings are consistent with the cross-sectional and longitudinal seroepidemiological studies that have showed that large proportions of children and adults have serum antibodies to these four nonSARS human coronavirus strains(7). The Seroprevalences of the zoonotic human coronaviruses (SARS, MERS and SARS-2) have been reported to be below $5 \%$ in humans especially among those who do not come into contact with the intermediate hosts for these viruses (36-39). Such results suggest that unknown asymptomatic and subclinical infections or unrecognized cases might exist in the general population that can underscore the role of human to human transmission.

Previous studies have also shown that Enzyme-linked immunosorbent assays are useful in diagnosis of $\mathrm{HCoV}$ infections with the biggest challenge being cross reactive antibodies that can give rise to false positives especially when the study aims at detecting a specific virus strain. Several studies have made it clear that cross reactivity on serological testing occurs especially when the target is the nucleocapsid proteins $(40,41)$. The nucleocapsid protein has been recognized as an important target in the development of human coronavirus diagnostics because it induces a good antibody response (42). However, this nucleocapsid protein has a highly conserved region that occurs in the N-terminal portion which induces cross reactivity antibodies among human coronaviruses $(34,43,44)$. Whereas this cross reactivity is a setback, diagnostic kits that detect antibodies to the nucleoprotein can have a qualitative screening role during testing of samples. Compared to the nucleocapsid protein, the spike protein contains multiple conformational epitopes that are major inducers of neutralizing antibodies. These antibodies are more specific and more recommended in the confirmatory testing of a particular type of human coronavirus because the spike protein has the least sequence conservation among human coronavirus proteins $(33,45,46)$.

Human coronavirus infections are commonly diagnosed by polymerase reaction using cDNA synthesized from RNA extracts from respiratory tract samples. However, for the establishment exposure rates among the population, seroepidemiological studies offer an important avenue for painting a picture on $\mathrm{HCoV}$ infections. Although an increasing threat of zoonosis and emerging pandemics caused by HCoVs is now more obvious than ever, there is little known about their seroprevalence in most developing countries especially Uganda. Here we report the seroprevalence of human coronavirus antibodies in hospital-based surveillance sentinel sites in Uganda before the global pandemic of SARS-CoV-2.

\section{Methods}

The study was conducted among the Makerere University Walter Reed project established hospital-based sentinel sites for surveillance activities on acute febrile illnesses. Samples were obtained from the five 
hospital-based sites were established for surveillance which include Jinja (Eastern Uganda), Mulago (Central Uganda, Capital), Bwera (Western Uganda), Gulu (Northern Uganda) and Bombo Military hospital (Central Uganda) (Fig. 1).

Patients reporting to these sites aged 6 months or older presenting influenza like illness (ILI) were enrolled after informed consent for the adults while for minors, informed consent was obtained from their parents or legal guardians. All methods in this study were carried out in accordance with relevant guidelines and regulations. Blood samples were drawn from the volunteers and transported to the Emerging Infectious Diseases Laboratory. The serum samples were kept at $-20^{\circ} \mathrm{C}$. An ILI patient was defined as any individual having a fever of temperature $38^{\circ} \mathrm{C}$ and above, plus clinical signs including cough, sore throat, myalgia and headache according to the established guidelines by WHO with modifications in other studies(47). Demographic characteristics of the patients and other related illness and symptoms were recorded on a standardized form.

The archived serum samples were retrieved, thawed to room temperature and tested using a commercial Qualitative Human Coronavirus IgG ELISA kit Cat. No. MBS9301037 (renamed HCoV-HKU-IgG ELISA kit) from MyBiosecure. The kit uses a nucleoprotein, aa 340-390 to coat the wells and according to the manufacturer, since there is significant homology among the various human coronavirus strains with regards to the coded for proteins, there is significant cross reactivity beyond SARS-CoV HKU-39849 2003. This gives the kit a qualitative ability to detect the presence of human coronavirus antibodies in a sample. The assay was done according to manufacturer's recommendation. Briefly, the reagents and samples were brought to room temperature, the positive and negative control wells as well as the sample wells were set. $50 \mu \mathrm{l}$ each of the positive control, negative control and undiluted samples were added to respective wells. $100 \mu \mathrm{l}$ of HRP- conjugate reagent was added to all the wells, covered with an adhesive strip and then incubated for 60 minutes at $37^{\circ} \mathrm{C}$. The plates were then washed four times after which $50 \mu \mathrm{l}$ of Chromogen Solution A and $50 \mu \mathrm{l}$ of Chromogen Solution B was added to each well successively, mixed gently and incubated for 15 minutes at $37^{\circ} \mathrm{C}$ when protected from light. $50 \mu$ of stop solution was added to each well and then Optical Density read at $450 \mathrm{~nm}$ using an ELISA reader at five minutes after the addition of the stop solution. The cut off for positivity were calculated per assay as the average OD value for the negative control wells +0.15 .

\section{Results}

\section{Demographic and clinical characteristics of enrolled volunteers}

A total of 377 samples were randomly selected from 1485 samples that had been collected from the Sentinel sites between 2017 and 2018. The samples size of 377 was computed using the formula adapted from Veterinary Epidemiology by Michael Thrusfield at $95 \%$ confidence interval, prevalence of $50 \%$ (Xiuping et al., 2007) and precision of $5 \%$. The demographic profile of the samples is summarized in Table1. Majority of the samples (45\%) were from volunteers of 1-5 years of age and were gender balanced (48.8\% males, $51.2 \%$ females). 
Table 1

Demographic characteristics of the samples

\begin{tabular}{|c|c|}
\hline Demographic Characteristic & Numbers (\%) \\
\hline \multicolumn{2}{|l|}{ Gender } \\
\hline Male & $184(48.8 \%)$ \\
\hline Female & $193(51.2 \%)$ \\
\hline \multicolumn{2}{|l|}{ Age } \\
\hline$<1$ & $28(7.4 \%)$ \\
\hline $1-5$ & $171(45.4 \%)$ \\
\hline $6-10$ & $68(18.0 \%)$ \\
\hline $11-15$ & $27(7.2 \%)$ \\
\hline $16-20$ & $22(5.8 \%)$ \\
\hline$>20$ & $61(16.2 \%)$ \\
\hline \multicolumn{2}{|l|}{ Activity } \\
\hline Pre-school Children & $160(42.4 \%)$ \\
\hline Schooling / Students & 139 (36.9\%) \\
\hline Employed & $30(8.0 \%)$ \\
\hline Unemployed & $48(12.7 \%)$ \\
\hline
\end{tabular}

\section{Seropositivity Among The Samples}

Of the 377 serum samples analyzed, 330 (87.53\%) were seropositive while 47 (12.47\%) were seronegative (Table 2). There was no significant no significant difference in the seroprevalence of Human Coronavirus antibodies in the different sentinel sites $(95 \% \mathrm{Cl}$, p-value $=0.8)$. 
Table 2

Seroprevalence in different sites

\begin{tabular}{|llll|}
\hline Site & $\begin{array}{l}\text { Seropositive } \\
\text { Positive }\end{array}$ & $\begin{array}{l}\text { Seronegative } \\
\text { Negative }\end{array}$ & Seroprevalence (\%) \\
\hline Gulu $(n=76)$ & 64 & 12 & 84.21 \\
\hline Mulago $(n=79)$ & 64 & 15 & 81.01 \\
\hline Jinja $(n=68)$ & 66 & 2 & 97.06 \\
\hline Bwera $(n=76)$ & 70 & 6 & 92.16 \\
\hline Bombo $(n=78)$ & 66 & 12 & 84.62 \\
\hline Over all $(n=377)$ & 330 & 47 & 87.53 \\
\hline
\end{tabular}

When we examined the seroprevalence according to age groups (Table 3), age group 1-5 years had the highest seroprevalence $90.6 \%$ with $47 \%$ of the seropositives falling in this age group. Further, $63 \%$ of all the seropositives were in the age bracket $1-10$ years which also constituted $63 \%$ of all the samples. The percentage of the seropositive samples for each age was high with a mean of $86.63 \%$ and standard mean error 1.029 .

Table 3

showing seroprevalence according to groups

\begin{tabular}{|llll|}
\hline $\begin{array}{l}\text { Age group } \\
\text { years }(n)\end{array}$ & $\begin{array}{l}\text { Seropositive } \\
\text { samples }\end{array}$ & $\begin{array}{l}\text { \% Seropositive within } \\
\text { age group }\end{array}$ & $\begin{array}{l}\text { \% Seropositive in } \\
\text { total samples }\end{array}$ \\
\hline$<1(n=28)$ & 24 & 85.71 & 7.27 \\
\hline $1-5(n=171)$ & 155 & 90.64 & 46.97 \\
\hline $6-10(n=68)$ & 55 & 80.88 & 16.67 \\
\hline $11-15(n=27)$ & 23 & 85.19 & 6.97 \\
\hline $16-20(n=22)$ & 19 & 86.36 & 5.76 \\
\hline $20<(n=61)$ & 54 & 88.52 & 16.36 \\
\hline Total $(377)$ & 330 & 87.53 & \\
\hline
\end{tabular}

We categorized the results in two main groups (Table 4) to calculate the odds for seropositivity according to age of volunteers below five years and those above five years. The odds ratio of those seropositive with an age above 5 years with reference to those below 5 years was 0.62 . 
Table 4

showing the broad age categories

\begin{tabular}{|lll|}
\hline Age category & Seropositive samples & Odds Ratio \\
\hline Below 5(199) & $179(89.9 \%)$ & 1 \\
\hline above $5(178)$ & $151(84.8 \%)$ & 0.62 \\
\hline
\end{tabular}

\section{Seasonality Of The Seropositivity Among The Volunteers}

The seropositivity was generally high throughout the year with highest being recorded in March and the lowest in February and December as shown in Fig. 2.

\section{Discussions}

Human coronaviruses are known to have a wide distribution and endemic to most countries in the world but usually limited information is available on their presence and circulation in Sub-Saharan countries like Uganda. Conducting serosurvey studies is important in establishing baseline knowledge of endemic viruses in a community especially examining the extent of exposure of the population to coronaviruses. We report on the level seroprevalence of human coronaviruses in hospital-based sentinel sites in Uganda at a time when country and the world at large is facing a pandemic caused by SARS-CoV2. This will provide a picture about the possible level of exposure and population-based immunity against human coronaviruses.

The study observed a high seroprevalence (87.5\%) of human coronaviruses in volunteers that visited the hospital-based sentinel sites. This high seroprevalence was consistent with other studies elsewhere. A previous study showed that $91 \%$ of sera collected from individuals in Southern Iraq has antibodies against HCoVs 229E and OC43 (48). Further, a study that compared the prevalence of antibodies to four human coronaviruses (229E, OC43, NL63 and HKU 1) in serum and lower nasal secretions showed an average seroprevalence of $97 \%$ in serum of adult patients (49). This is still consistent with other studies that have shown that human coronaviruses have a global distribution $(7,50)$. Although in our study we did not screen for specific strain of human coronavirus, the result shows a great exposure of the volunteers to human coronaviruses. The hospital-based sentinel sites from which the samples were collected are major referral health centers in the respective regions in the country, thus this result give an overall picture of the seroprevalence of human coronavirus antibodies in the country. A previous surveillance study in hospital-based sites in Uganda showed 1.5\% PCR positivity for human coronaviruses which further proves that these viruses circulate within the population (51). The volunteers presented several symptoms like fever, headache, muscle pains, sore throat and cough that are associated with infections of human coronaviruses, it is probable that patients were infected with human coronaviruses although health centers rarely carry out diagnosis to prove the causes of the clinical signs presented beyond the commonly known infections (52-54). 
The qualitative Human coronaviruses antibody IgG ELISA kit that was used had its wells coated with a nucleoprotein, aa 340-390 (SARS corona HKU-39849)(55). There is no commercially available kit which can universally detect antibodies against all circulating coronaviruses but given that here is significant homology among the various human coronavirus strains with regards to the coded for proteins, there is significant cross reactivity beyond SARS-CoV HKU-39849 2003. This gives the kit a qualitative ability to detect and give an overall picture of the seroprevalence of human corona antibodies in the volunteers. IgG antibodies are known to be detected 4 days after onset of disease and may persist in patients for a period of 36 months in individual after recovery (56). Since the kit was not quantitative in nature, we did not establish the antibody titer in the samples which could be correlated with the time of infection. Never the less, this suggests that this observed high seroprevalence among volunteers could be due to a recent or earlier exposure to the human coronaviruses. Without corresponding PCR or culture experiments for the tested samples, it was not possible to confirm the presence and the infectiveness of the virus in the volunteers. It is known that when viruses invade the body, immune responses are induced in form of host defensive mechanisms among which is the production of neutralizing antibodies that prevent the virus from invading new cells and initiate the killing of infected cells and these antibodies stay long enough after the virus has been cleared (57). With no deaths previously reported due to human coronavirus infection, it probable that the defense mechanisms of volunteers are strong enough to clear the viral infection.

In this study, seropositivity was highest among children between 0-5 years compared to other age group ranges. The samples were selected completely at random therefore the numbers per age group is not equal which limits our degree of comparison. However, it is true that the seroprevalence of human coronaviruses antibodies vary greatly depending on the age of the population $(58,59)$. The computed odds ratios show that children under five years are more likely to be seropositive compared to individuals above 5 years of age. This agrees with the study which suggested that primary exposure to and infection by HCoVs takes place in childhood $(7,60)(61-63)$. The first 10 years of an individual usually sees them transit from purely parent protection and isolation to open exposure in school settings. It is probable that this exposure makes this age group more susceptible to contracting human coronaviruses resulting in the high seropositivity.

In terms of seasonality, the seroprevalence was generally constant throughout the year with slight variations observed. The highest seroprevalence was observed in March and the lowest in February and December. Although no data about climate was analyzed during this study, Uganda experiences little annual variation in temperature with the average coolest months between June and September, while the rainy seasons occur between March and June, then between September and November, notwithstanding that the Country experiences occasional light rains almost through the year especially for regions around Lake Victoria (64). These weather conditions seem to favor the circulation of human coronavirus which elsewhere have been documented to circulate more frequently during winter season (14). This is in line with the argument that the activity of human coronaviruses is sporadic throughout the year with no clear seasonality (65) unlike influenza whose seasonality in Uganda has been established (66). However, there 
is need to continuously do serosurveillance over a longer period of time to establish and describe the seasonality of Human coronaviruses in Uganda.

This study had limitations. The small sample size that was analyzed, the sentinel sites are not evenly distributed in the country, the lack of measurement of climatic factor to relate with the observed seroprevalence.

\section{Conclusion}

This study reports the high seroprevalence of antibodies against Human coronaviruses. Human coronaviruses are important emerging pathogens and currently the world is facing a devastating pandemic caused by SARS-2, there is therefore need for continuous viral surveillance. There is need to determine whether these antibodies possessed due to previous exposure to coronaviruses can offer protection to these emerging viral strains.

\section{Abbreviations}

HCoV: Human Coronavirus

SARS: Severe Acute Respiratory Syndrome

MERS: Middle East Respiratory Syndrome

cDNA: complementary DNA

\section{Declarations}

\section{Ethical approval and consent to participate:}

This study was conducted under an approved wider surveillance study by Makerere University Walter Reed Project. The project was internally approved by Makerere University School of Public Health Institutional Review Board (IRB) and externally by Walter Reed Army Institute of Research. The adult Patients at each sentinel site were enrolled after informed consent. The minors (below 18 years) were enrolled after informed consent from parents and legal guardians

Consent for publication: Not applicable

Availability of data and materials: All data generated is available from the corresponding author on reasonable request

\section{Competing interests}

The Authors declare that they have no competing interests 


\section{Funding}

This work was performed with support from the Defense Threat Reduction Agency Grant \# Makerere University Walter Reed Project (MUWRP) (Byarugaba PI).

\section{Authors' contribution}

MNE did the bench work, drafted the manuscript and the included figures

RT reviewed the manuscript

FMW reviewed the manuscript

EM reviewed the manuscript

JK reviewed the manuscript

HK reviewed the manuscript

MM reviewed the manuscript

BE participated in sample collection

TT participated in sample collection

UQA participated in sample collection

DKB is the Principal Investigator of the project

\section{Acknowledgment}

We acknowledge the staff of WUWRP that work at the Emerging Infectious Disease Laboratory.

\section{References}

1. Gorbalenya $A E$, Enjuanes L, Ziebuhr J, Snijder EJ. Nidovirales: evolving the largest RNA virus genome. Virus research. 2006;117(1):17-37. https://doi.org/10.1016/j.virusres.2006.01.017

2. Masters PS. The molecular biology of coronaviruses. Advances in virus research. 2006;66:193-292. https://doi.org/10.1016/S0065-3527(06)66005-3

3. McBride R, Fielding BC. The role of severe acute respiratory syndrome (SARS)-coronavirus accessory proteins in virus pathogenesis. Viruses. 2012;4(11):2902-23. https://doi.org/10.3390/v4112902

4. Lim YX, Ng YL, Tam JP, Liu DX. Human Coronaviruses: A Review of Virus-Host Interactions. Diseases. 2016;4(3):26. https://doi.org/10.3390/diseases4030026 
5. Lai MM, Cavanagh D. The molecular biology of coronaviruses. Advances in virus research. 48 : Elsevier; 1997. p. 1-100. https://doi.org/10.1016/S0065-3527(08)60286-9

6. Brian D, Baric R. Coronavirus genome structure and replication. Coronavirus replication and reverse genetics: Springer; 2005. p. 1-30. doi: 10.1007/3-540-26765-4_1

7. Zhou W, Wang W, Wang H, Lu R, Tan W. First infection by all four non-severe acute respiratory syndrome human coronaviruses takes place during childhood. BMC infectious diseases. 2013;13(1):433. DOI: 10.1186/1471-2334-13-433

8. Bredenbeek PJ, Snijder EJ, Noten AF, den Boon JA, Schaaper WM, Horzinek MC, et al. The polymerase gene of corona-and toroviruses: evidence for an evolutionary relationship. Coronaviruses and their Diseases: Springer; 1990. p. 307-16. Part of the Advances in Experimental Medicine and Biology book series (AEMB, volume 276)

9. Siddell SG. The coronaviridae. The coronaviridae: Springer; 1995. p. 1-10. Part of the The Viruses book series (VIRS)

10. Wege H, Schliephake A, Körner H, Flory E, Wege H. An immunodominant CD4+ T cell site on the nucleocapsid protein of murine coronavirus contributes to protection against encephalomyelitis. Journal of general virology. 1993;74(7):1287-94. https://doi.org/10.1099/0022-1317-74-7-1287

11. Consortium CSME. Molecular evolution of the SARS coronavirus during the course of the SARS epidemic in China. Science. 2004;303(5664):1666-9. DOI: 10.1126/science.1092002

12. Memish ZA, Cotten M, Meyer B, Watson SJ, Alsahafi AJ, Al Rabeeah AA, et al. Human infection with MERS coronavirus after exposure to infected camels, Saudi Arabia, 2013. Emerging infectious diseases. 2014;20(6):1012. https://dx.doi.org/10.3201\%2Feid2006.140402

13. Lai C-C, Shih T-P, Ko W-C, Tang H-J, Hsueh P-R. Severe acute respiratory syndrome coronavirus 2 (SARS-CoV-2) and corona virus disease-2019 (COVID-19): the epidemic and the challenges. International journal of antimicrobial agents. 2020:105924. https://doi.org/10.1016/j.ijantimicag.2020.105924

14. van der Hoek L. Human coronaviruses: what do they cause? Antiviral therapy. 2007;12(4 Pt B):651.

15. Pene F, Merlat A, Vabret A, Rozenberg F, Buzyn A, Dreyfus F, et al. Coronavirus 229E-related pneumonia in immunocompromised patients. Clinical infectious diseases. 2003;37(7):929-32. https://doi.org/10.1086/377612

16. Gorse GJ, O'Connor TZ, Hall SL, Vitale JN, Nichol KL. Human coronavirus and acute respiratory illness in older adults with chronic obstructive pulmonary disease. The Journal of infectious diseases. 2009;199(6):847-57. doi: 10.1086/597122

17. Graham RL, Donaldson EF, Baric RS. A decade after SARS: strategies for controlling emerging coronaviruses. Nature Reviews Microbiology. 2013;11(12):836-48. DOI: 10.1038/nrmicro3143

18. Ip M, Chan PK, Lee N, Wu A, Ng TK, Chan L, et al. Seroprevalence of antibody to severe acute respiratory syndrome (SARS) - associated coronavirus among health care workers in SARS and nonSARS medical wards. Clinical Infectious Diseases. 2004;38(12):e116-e8. doi: 10.1086/421019 
19. Frieman M, Baric R. Mechanisms of severe acute respiratory syndrome pathogenesis and innate immunomodulation. Microbiol Mol Biol Rev. 2008;72(4):672-85. doi: 10.1128/MMBR.00015-08

20. Peiris J, Guan Y, Yuen K. Severe acute respiratory syndrome. Nature medicine. 2004;10(12):S88-S97. DOI: $10.1038 / \mathrm{nm} 1143$

21. Tu C, Crameri G, Kong X, Chen J, Sun Y, Yu M, et al. Antibodies to SARS coronavirus in civets. Emerging infectious diseases. 2004;10(12):2244. 10.3201 / eid1012.040520

22. Zaki AM, Van Boheemen S, Bestebroer TM, Osterhaus AD, Fouchier RA. Isolation of a novel coronavirus from a man with pneumonia in Saudi Arabia. New England Journal of Medicine. 2012;367(19):1814-20. DOI: 10.1056/NEJMoa1211721

23. Kim Y, Cheon S, Min C-K, Sohn KM, Kang YJ, Cha Y-J, et al. Spread of mutant Middle East respiratory syndrome coronavirus with reduced affinity to human CD26 during the South Korean outbreak. MBio. 2016;7(2):e00019-16. DOI:10.1128/mBio.00019-16

24. Cowling BJ, Park M, Fang VJ, Wu P, Leung GM, Wu JT. Preliminary epidemiologic assessment of MERS-CoV outbreak in South Korea, May-June 2015. Euro surveillance: bulletin Europeen sur les maladies transmissibles= European communicable disease bulletin. 2015;20(25). doi: 10.2807/1560-7917.es2015.20.25.21163

25. Kim T-H, Lee H-H. Considerations left behind Middle East respiratory syndrome coronavirus (MERS-

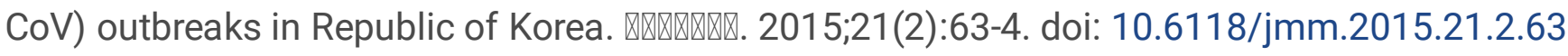

26. Li Q, Guan X, Wu P, Wang X, Zhou L, Tong Y, et al. Early transmission dynamics in Wuhan, China, of novel coronavirus-infected pneumonia. New England Journal of Medicine. 2020. DOI: 10.1056/NEJMoa2001316

27. Gorbalenya AE. Severe acute respiratory syndrome-related coronavirus-The species and its viruses, a statement of the Coronavirus Study Group. BioRxiv. 2020. doi:https://doi.org/10.1101/2020.02.07.937862

28. Chen N, Zhou M, Dong X, Qu J, Gong F, Han Y, et al. Epidemiological and clinical characteristics of 99 cases of 2019 novel coronavirus pneumonia in Wuhan, China: a descriptive study. The Lancet. 2020;395(10223):507-13. DOl:https://doi.org/10.1016/S0140-6736(20)30211-7

29. Lu R, Zhao X, Li J, Niu P, Yang B, Wu H, et al. Genomic characterisation and epidemiology of 2019 novel coronavirus: implications for virus origins and receptor binding. The Lancet. 2020;395(10224):565-74. DOl:https://doi.org/10.1016/S0140-6736(20)30251-8

30. Chang D, Lin M, Wei L, Xie L, Zhu G, Cruz CSD, et al. Epidemiologic and clinical characteristics of novel coronavirus infections involving 13 patients outside Wuhan, China. Jama. 2020. doi:10.1001/jama.2020.1623

31. Carlos WG, Dela Cruz CS, Cao B, Pasnick S, Jamil S. Novel wuhan (2019-nCoV) coronavirus. American journal of respiratory and critical care medicine. 2020;201(4):P7-P8. https://doi.org/10.1164/rccm.2014P7

32. Severance EG, Bossis I, Dickerson FB, Stallings CR, Origoni AE, Sullens A, et al. Development of a nucleocapsid-based human coronavirus immunoassay and estimates of individuals exposed to 
coronavirus in a US metropolitan population. Clinical and Vaccine Immunology. 2008;15(12):180510. DOI:10.1128/CVI.00124-08

33. Woo PC, Lau SK, Chu C-m, Chan K-h, Tsoi H-w, Huang Y, et al. Characterization and complete genome sequence of a novel coronavirus, coronavirus HKU1, from patients with pneumonia. Journal of virology. 2005;79(2):884-95. doi: 10.1128/JVI.79.2.884-895.2005

34. Chan C, Tse H, Wong S, Woo P, Lau S, Chen L, et al. Examination of seroprevalence of coronavirus HKU1 infection with S protein-based ELISA and neutralization assay against viral spike pseudotyped virus. Journal of clinical virology. 2009;45(1):54-60. doi: 10.1016/j.jcv.2009.02.011

35. Gorse GJ, Patel GB, Vitale JN, O'Connor TZ. Prevalence of antibodies to four human coronaviruses is lower in nasal secretions than in serum. Clinical and Vaccine Immunology. 2010;17(12):1875-80. DOI:10.1128/CVI.00278-10

36. Leung G, Lim W, Ho L-M, Lam T-H, Ghani A, Donnelly C, et al. Seroprevalence of IgG antibodies to SARS-coronavirus in asymptomatic or subclinical population groups. Epidemiology \& Infection. 2006;134(2):211-21. doi: 10.1017/S0950268805004826.

37. Gierer S, Hofmann-Winkler H, Albuali WH, Bertram S, Al-Rubaish AM, Yousef AA, et al. Lack of MERS coronavirus neutralizing antibodies in humans, eastern province, Saudi Arabia. Emerging Infectious Diseases. 2013;19(12):2034. DOI: 10.3201/eid1912.130701

38. Müller MA, Meyer B, Corman VM, Al-Masri M, Turkestani A, Ritz D, et al. Presence of Middle East respiratory syndrome coronavirus antibodies in Saudi Arabia: a nationwide, cross-sectional, serological study. The Lancet Infectious Diseases. 2015;15(5):559-64. doi: 10.1016/S14733099(15)70090-3

39. Sood N, Simon P, Ebner P, Eichner D, Reynolds J, Bendavid E, et al. Seroprevalence of SARS-CoV-2Specific Antibodies Among Adults in Los Angeles County, California, on April 10-11, 2020. Jama. 2020. doi:10.1001/jama.2020.8279

40. Chan K, Cheng V, Woo P, Lau S, Poon L, Guan Y, et al. Serological responses in patients with severe acute respiratory syndrome coronavirus infection and cross-reactivity with human coronaviruses 229E, OC43, and NL63. Clinical and diagnostic laboratory immunology. 2005;12(11):1317-21. doi: 10.1128/CDLI.12.11.1317-1321.2005

41. Che X-y, Qiu L-w, Liao Z-y, Wang Y-d, Wen K, Pan Y-x, et al. Antigenic Cross-Reactivity between Severe Acute Respiratory Syndrome-Associated Coronavirus and Human Coronaviruses 229E and OC43. Journal of Infectious Diseases. 2005;191(12):2033-7. DOI: 10.1086/430355

42. Mourez T, Vabret A, Han Y, Dina J, Legrand L, Corbet S, et al. Baculovirus expression of HCoV-OC43 nucleocapsid protein and development of a Western blot assay for detection of human antibodies against HCoV-OC43. Journal of virological methods. 2007;139(2):175-80. doi: 10.1016/j.jviromet.2006.09.024.

43. Rota PA, Oberste MS, Monroe SS, Nix WA, Campagnoli R, Icenogle JP, et al. Characterization of a novel coronavirus associated with severe acute respiratory syndrome. science. 2003;300(5624):1394-9. doi: 10.1126/science.1085952 
44. Patrick DM, Petric M, Skowronski DM, Guasparini R, Booth TF, Krajden M, et al. An outbreak of human coronavirus OC43 infection and serological cross-reactivity with SARS coronavirus. Canadian Journal of Infectious Diseases and Medical Microbiology. 2006;17. doi: 10.1155/2006/152612

45. Woo PC, Lau SK, Wong BH, Chan K-H, Hui W-T, Kwan GS, et al. False-positive results in a recombinant severe acute respiratory syndrome-associated coronavirus (SARS-CoV) nucleocapsid enzyme-linked immunosorbent assay due to HCoV-OC43 and HCoV-229E rectified by Western blotting with recombinant SARS-CoV spike polypeptide. Journal of clinical microbiology. 2004;42(12):5885-8. DOI:10.1128/JCM.42.12.5885-5888.2004

46. Maache M, Komurian-Pradel F, Rajoharison A, Perret M, Berland J-L, Pouzol S, et al. False-positive results in a recombinant severe acute respiratory syndrome-associated coronavirus (SARS-CoV) nucleocapsid-based western blot assay were rectified by the use of two subunits (S1 and S2) of spike for detection of antibody to SARS-CoV. Clinical and vaccine immunology. 2006;13(3):409-14. doi: 10.1128/CVI.13.3.409-414.2006.

47. Boivin G, Hardy I, Tellier G, Maziade J. Predicting influenza infections during epidemics with use of a clinical case definition. Clinical infectious diseases. 2000;31(5):1166-9. DOI: 10.1086/317425

48. Hasony HJ, Macnaughton MR. Prevalence of human coronavirus antibody in the population of southern Iraq. Journal of medical virology. 1982;9(3):209-

16. https://doi.org/10.1002/jmv.1890090308

49. Gorse GJ, Patel GB, Vitale JN, O'Connor TZ. Prevalence of antibodies to four human coronaviruses is lower in nasal secretions than in serum. Clin Vaccine Immunol. 2010;17(12):1875-80.

DOI:10.1128/CVI.00278-10

50. Woo PC, Lau SK, Huang Y, Yuen K-Y. Coronavirus diversity, phylogeny and interspecies jumping. Experimental Biology and Medicine. 2009;234(10):1117-27. DOI: 10.3181/0903-MR-94

51. Mimbe DE, Byarugaba D, Erima B, Mworozi E, Millard M, Tugume T, et al. Viral causes of Influenza Like Illness in Uganda, 2008 to 2017. Online Journal of Public Health Informatics. 2018;10(1). https://doi.org/10.5210/ojphi.v10i1.8990

52. Mäkelä MJ, Puhakka T, Ruuskanen O, Leinonen M, Saikku P, Kimpimäki M, et al. Viruses and bacteria in the etiology of the common cold. Journal of clinical microbiology. 1998;36(2):539-42. DOI: 10.1128/JCM.36.2.539-542.1998

53. Balinandi S, Bakamutumaho B, Kayiwa JT, Ongus J, Oundo J, Awor AC, et al. The viral aetiology of influenza-like illnesses in Kampala and Entebbe, Uganda, 2008. African journal of laboratory medicine. 2013;2(1). doi: 10.4102/ajlm.v2i1.65

54. Soběslavský O, Sebikari S, Harland P, Skrtić N, Fayinka O, Soneji A. The viral etiology of acute respiratory infections in children in Uganda. Bulletin of the World Health Organization. 1977;55(5):625. https://apps.who.int/iris/handle/10665/261117

55. van den Worm SH, Eriksson KK, Zevenhoven JC, Weber F, Züst R, Kuri T, et al. Reverse genetics of SARS-related coronavirus using vaccinia virus-based recombination. PloS one. 2012;7(3). doi: 10.1371/journal.pone.0032857 
56. Cao W-C, Liu W, Zhang P-H, Zhang F, Richardus JH. Disappearance of antibodies to SARS-associated coronavirus after recovery. New England Journal of Medicine. 2007;357(11):1162-3.

DOI: 10.1056/NEJMc070348

57. Newton AH, Cardani A, Braciale TJ, editors. The host immune response in respiratory virus infection: balancing virus clearance and immunopathology. Seminars in immunopathology; 2016: Springer. doi: $10.1007 / \mathrm{s} 00281-016-0558-0$

58. Greenberg SB, editor Update on human rhinovirus and coronavirus infections. Seminars in respiratory and critical care medicine; 2016: Thieme Medical Publishers. DOI: 10.1055/s-0036-1584797

59. Severance EG, Bossis I, Dickerson FB, Stallings CR, Origoni AE, Sullens A, et al. Development of a nucleocapsid-based human coronavirus immunoassay and estimates of individuals exposed to coronavirus in a US metropolitan population. Clin Vaccine Immunol. 2008;15(12):1805-10.

DOI:10.1128/CVI.00124-08

60. Shao X, Guo X, Esper F, Weibel C, Kahn JS. Seroepidemiology of group I human coronaviruses in children. Journal of clinical virology. 2007;40(3):207-13. doi: 10.1016/j.jcv.2007.08.007

61. Gaunt ER, Hardie A, Claas EC, Simmonds P, Templeton KE. Epidemiology and clinical presentations of the four human coronaviruses 229E, HKU1, NL63, and OC43 detected over 3 years using a novel multiplex real-time PCR method. Journal of clinical microbiology. 2010;48(8):2940-7. doi: 10.1128/JCM.00636-10

62. Principi N, Bosis S, Esposito S. Effects of coronavirus infections in children. Emerging infectious diseases. 2010;16(2):183. doi: 10.3201/eid1602.090469

63. Hendley JO, Fishburne HB, Gwaltney Jr JM. Coronavirus infections in working adults: eight-year study with 229 E and OC 43. American Review of Respiratory Disease. 1972;105(5):805-11. DOI: 10.1164/arrd.1972.105.5.805

64. Hisali E, Birungi P, Buyinza F. Adaptation to climate change in Uganda: evidence from micro level data. Global environmental change. 2011;21(4):1245-61 https://doi.org/10.1016/j.gloenvcha.2011.07.005

65. Lu R, Yu X, Wang W, Duan X, Zhang L, Zhou W, et al. Characterization of human coronavirus etiology in Chinese adults with acute upper respiratory tract infection by real-time RT-PCR assays. PloS one. 2012;7(6). DOI: 10.1371/journal.pone.0038638

66. Byarugaba DK, Ducatez MF, Erima B, Mworozi EA, Millard M, Kibuuka H, et al. Molecular epidemiology of influenza A/H3N2 viruses circulating in Uganda. PloS one. 2011;6(11). https://doi.org/10.1371/journal.pone.0027803

\section{Figures}




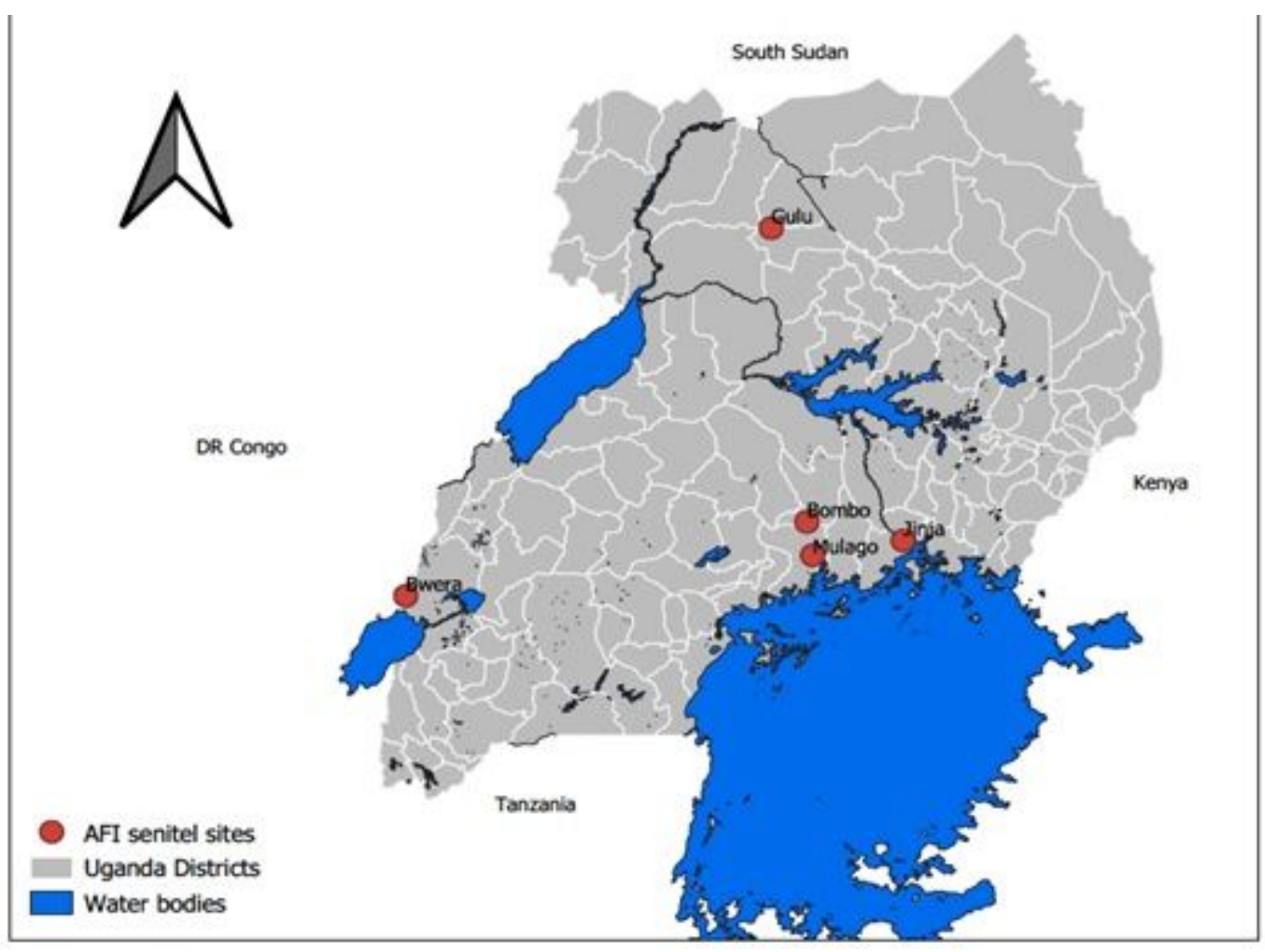

\section{Figure 1}

Map showing the Hospital based surveillance Sentinel sites in Uganda

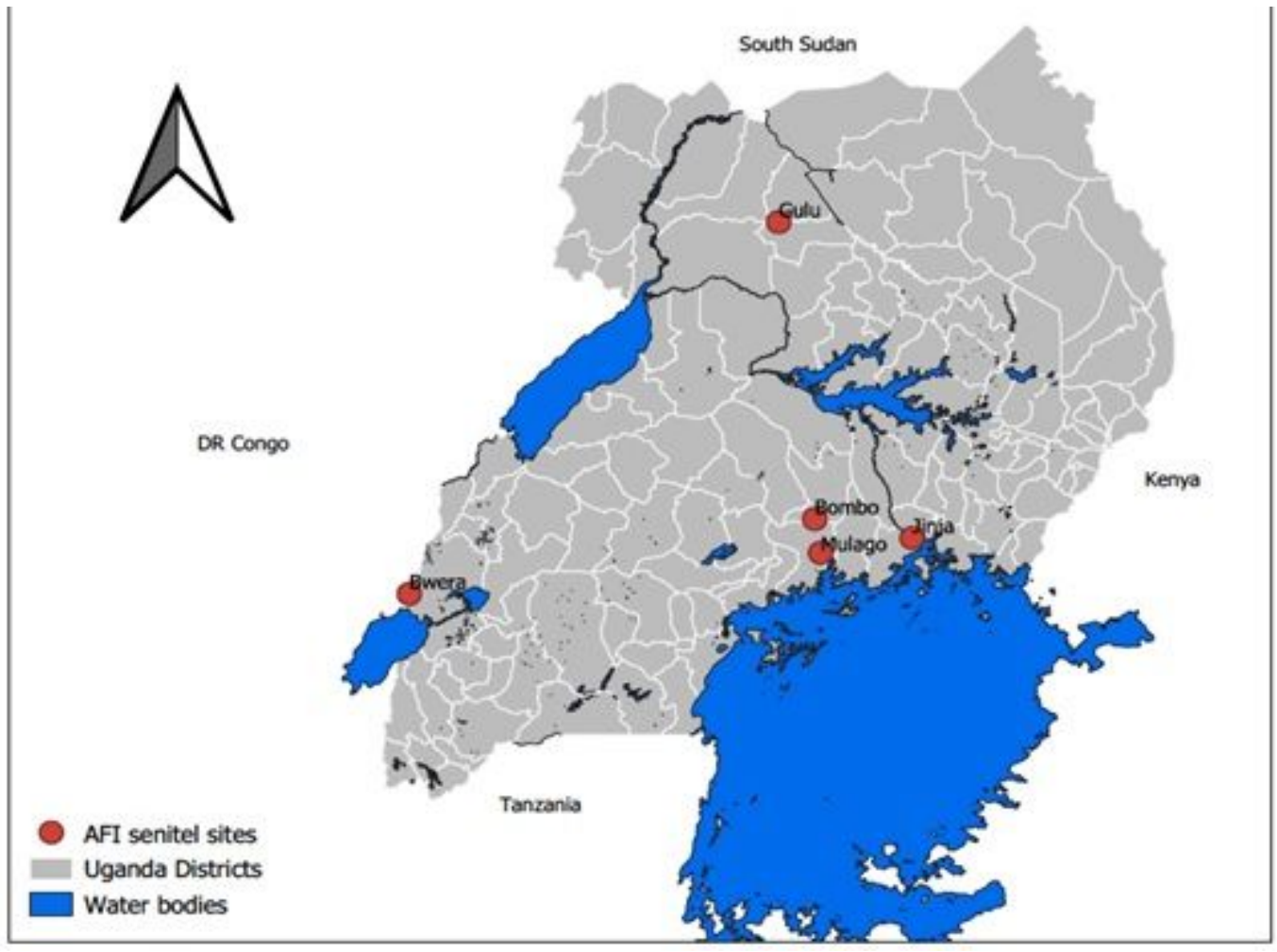

\section{Figure 1}

Map showing the Hospital based surveillance Sentinel sites in Uganda 


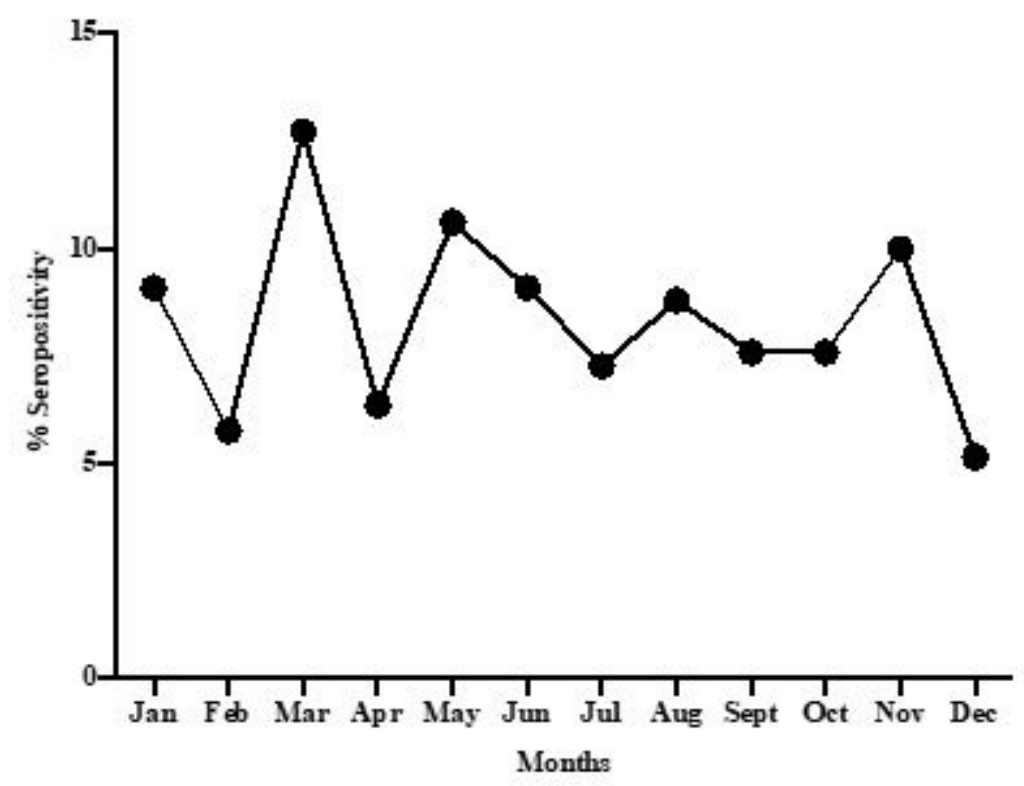

Figure 2

showing the variation of percentage seropositivity across the year

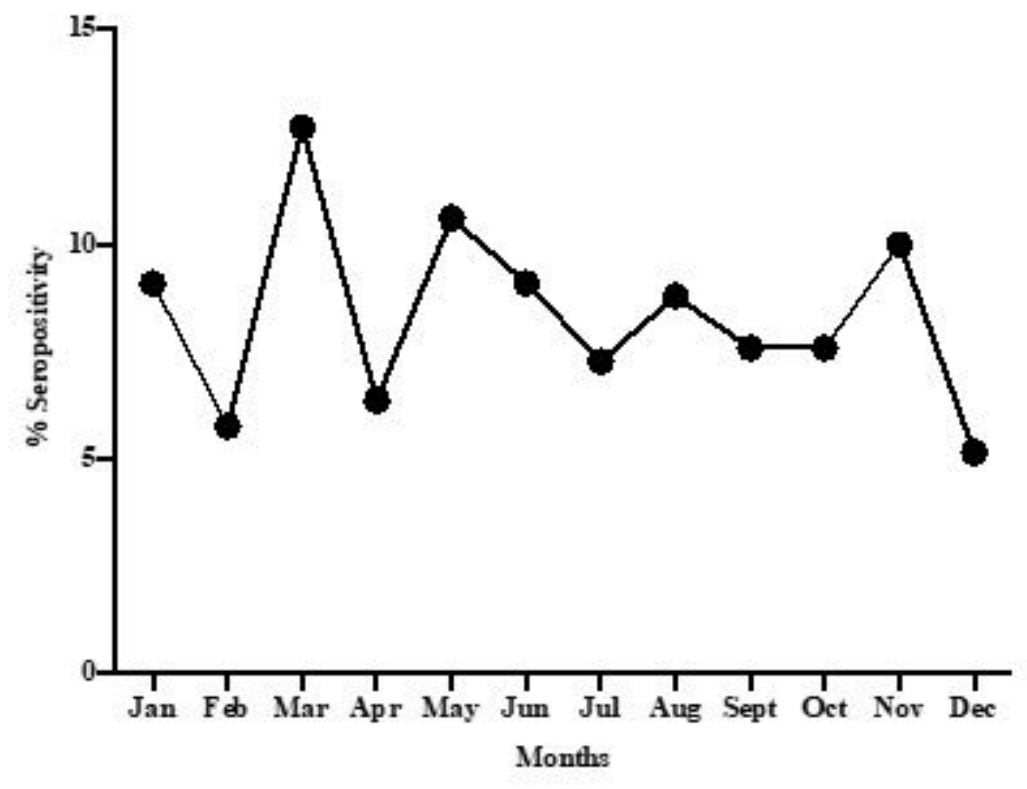

Figure 2

showing the variation of percentage seropositivity across the year 